\title{
Perioperative Cardioprotection by Remote Ischemic Conditioning
}

\author{
Youn Joung Cho and Won Ho Kim * (1) \\ Department of Anesthesiology and Pain Medicine, Seoul National University Hospital, \\ Seoul National University College of Medicine, Seoul 03080, Korea; mingming7@gmail.com \\ * Correspondence: wonhokim.ane@gmail.com; Tel.: +82-2-2072-3484
}

Received: 25 August 2019; Accepted: 27 September 2019; Published: 29 September 2019

check for updates

\begin{abstract}
Remote ischemic conditioning has been investigated for cardioprotection to attenuate myocardial ischemia/reperfusion injury. In this review, we provide a comprehensive overview of the current knowledge of the signal transduction pathways of remote ischemic conditioning according to three stages: Remote stimulus from source organ; protective signal transfer through neuronal and humoral factors; and target organ response, including myocardial response and coronary vascular response. The neuronal and humoral factors interact on three levels, including stimulus, systemic, and target levels. Subsequently, we reviewed the clinical studies evaluating the cardioprotective effect of remote ischemic conditioning. While clinical studies of percutaneous coronary intervention showed relatively consistent protective effects, the majority of multicenter studies of cardiac surgery reported neutral results although there have been several promising initial trials. Failure to translate the protective effects of remote ischemic conditioning into cardiac surgery may be due to the multifactorial etiology of myocardial injury, potential confounding factors of patient age, comorbidities including diabetes, concomitant medications, and the coadministered cardioprotective general anesthetic agents. Given the complexity of signal transfer pathways and confounding factors, further studies should evaluate the multitarget strategies with optimal measures of composite outcomes.
\end{abstract}

Keywords: remote ischemic conditioning; cardioprotection; neuronal pathway; humoral pathway; cardiac surgery; propofol; diabetes

\section{Background}

Myocardial infarction results in tissue damage as a consequence of both ischemia and subsequent reperfusion injury [1]. However, a brief episode of myocardial ischemia and reperfusion can protect the myocardium from prolonged ischemia/reperfusion by activating the molecular defense mechanisms [2]. This protective conditioning of the myocardium can be induced locally by a brief episode of occlusion/reperfusion of the coronary artery. However, remote conditioning is also possible through brief episodes of ischemia/reperfusion of a distant limb: This transfer of protection is called remote ischemic conditioning.

In the original animal studies, repeated brief preceding cycles of occlusion/reperfusion of the left circumflex artery reduced the size of a subsequent myocardial infarct in the left anterior descending artery territory [3]. Initially, this effect was regarded as an incidental finding. However, subsequent studies confirmed the protective effect and found that protection can be transferred from a number of distant tissues and organs [4,5]. Ischemic conditioning is now regarded as a systemic response, which can be triggered by various stimuli in addition to ischemia/reperfusion, and can be elicited at different tissues and organs [6]. Remote ischemic conditioning confers protection before or even after the myocardial infarct-causing ischemia. Remote ischemic conditioning is now categorized as preconditioning (before myocardial ischemia), perconditioning (during myocardial 
ischemia), or postconditioning (after the target organ ischemia) [7]. Delayed remote conditioning refers to the procedure in which the time interval between conditioning and target ischemia is longer than several minutes [8]. Although an exact dose-response relationship has not been established, previous studies suggested that the frequency and duration of remote ischemic conditioning episodes, rather than the volume of remote ischemic tissue affected, determine the degree of resulting target tissue protection $[9,10]$. The mechanism by which remote ischemic conditioning transfers the protective signal is largely unclear [11]. Both humoral and neuronal factors seem to be engaged in the transfer, with interactions reported between the two factors [2].

Clinical studies provided evidence of the remote ischemic conditioning effect. Transient episodes of ischemia/reperfusion induced by cycles of inflation and deflation of a blood pressure cuff placed on the upper limb protected the contralateral upper limb from ischemia/reperfusion-induced endothelial dysfunction [12,13]. In a subsequent clinical trial, remote ischemic preconditioning (RIPC) by cycles of ischemia/reperfusion reduced the extent of myocardial injury measured by troponin release during elective coronary artery bypass surgery [4]. A subsequent study has reported that the remote ischemic perconditioning implemented in an ambulance vehicle during the transport of patients with acute myocardial infarction to the hospital reduced myocardial infarct size measured by single-photon emission computed tomography [14]. RIPC was shown to provide protection against acute kidney injury in patients undergoing cardiac surgery [15]. These promising studies elicited many subsequent clinical trials to reproduce the protective effects and laboratory studies to elucidate the mechanism of transfer of protection.

\section{Signal Transduction}

\subsection{Remote Stimulus}

Remote ischemic conditioning elicits tissue protection as a result of a remote stimulus. In addition to the repeated cycles of ischemia/reperfusion of a limb or organ, a number of remote stimuli were shown to induce protective effects in the target organ. The stimuli include: (i) Brief cycles of ischemia/reperfusion of a limb or organ [16-20]; (ii) mechanical stimuli, including surgical skin incision [21]; (iii) chemical-pharmacologic stimuli, including autacoids (such as adenosine [22], bradykinin [23]), or capsaicin [24]; and (iv) electrical stimuli, including electroacupuncture or percutaneous electrical nerve stimulation $[23,24]$. As the dose-response relationship has not been established for any of these stimuli, previous comparisons of different stimuli have limited value $[19,20]$. Peripheral sensory nerve stimulation is involved in all these stimuli. The extent to which peripheral nerve stimulation or additional mechanisms are involved in remote ischemic conditioning, however, is uncertain $[6,25]$.

\subsection{Signal Transfer-Neuronal and Humoral Factors}

Both humoral and neuronal factors are involved in the transfer of protective signals from the site of a remote stimulus to the target organ. However, the exact amount or nature of humoral and neuronal mediators remain uncertain $[2,6,26]$. Previous studies that investigated neuronal or humoral mediators are summarized in Table 1.

Neuronal factors are engaged in the remote conditioning of the heart [27], as evidenced by a large number of studies suggesting their involvement. Bilateral cervical or subdiaphragmatic vagotomy and cell-specific neuronal silencing in the brain stem nucleus of the vagus nerve were found to abolish the reduction in myocardial infarct size in rats by remote ischemic conditioning [28]. Electrical stimulation of the vagus nerve confers effects similar to remote ischemic conditioning in pigs and rabbits [28,29]. Intrathecal lidocaine attenuated the effect of remote intrathecal morphine preconditioning by blocking spinal cord neuronal signal transmission [30]. Spinal cord transection at the T9-T10 level abrogated the effect of remote conditioning by three episodes of limb ischemia/reperfusion [31]. However, it is still not clear whether the involvement of the brain stem is mandatory for the transduction of the protective 
signal or which level of the spinal cord is involved in the pathway. A previous study reported that the effect of remote ischemic conditioning could be transferred to distant tissue in non-diabetic patients or diabetic patients without diabetic neuropathy. Conversely, the protection was not transferrable in diabetic patients with peripheral neuropathy, providing further evidence of a neuronal pathway [32].

It is evident that the humoral signal is transferred to the heart from the site of the remote stimuli. However, we do not know whether the same humoral factors underlie the effects elicited by different stimuli. Humoral cardioprotective signals can be identified in the plasma, plasma dialysate, or whole blood of the donor who underwent remote conditioning and can be transferred to a recipient by transfusion [2,33-35]. Previous animal studies revealed that the cardioprotection elicited by remote ischemic conditioning can be transferred to an isolated perfused heart of the same or even other species using plasma dialysate, diluted plasma, or whole blood $[2,33,35]$. However, the efficacy of cardioprotection was not compared between plasma dialysates at different dilutions, or between diluted plasma and whole blood. Investigation of successful humoral transfers have identified two key characteristics of humoral factors: The molecular size of humoral factors is less than 12 to $14 \mathrm{kDa}$ and humoral factors remain effective at plasma dilutions up to 1:50. Humoral factors were further determined to be thermolabile, lyophilizable, and hydrophobic, suggesting that humoral factors are proteins or peptides [35-37]. In healthy volunteers who underwent three cycles of forearm ischemia/reperfusion ( 5 min each), plasma dialysate could be used to transfer cardioprotection even after seven days [34]. A fluctuation in plasma proteins over time was observed, with up/downregulation detected by proteomic analysis of plasma obtained from healthy volunteers who underwent remote ischemic conditioning [38]. However, the factors were not identified, and the causal role of the proteins was not clearly determined.

A microRNA array found an increase in circulating microRNA144 levels following remote ischemic conditioning. Exogenous microRNA144 was shown to induce cardioprotection, while a specific antisense oligonucleotide abrogated the ability of remote ischemic conditioning to reduce infarct size [39]. Elevations in apolipoprotein A1 were identified by proteomic approaches in both human and rat plasma after remote conditioning [38,40]. Levels of endothelial RNase1 were increased in the blood of patients undergoing heart surgery after remote ischemic conditioning, suggesting it could be a humoral mediator [41]. However, a causal relationship was not proven because the troponin level was not reduced by conditioning in this particular study.

Autacoids, such as adenosine or bradykinin, are released during regional ischemic conditioning and exogenous administration of autacoid confers cardioprotection. Adenosine release into the spinal cord tissue was associated with reduced infarct size in response to remote conditioning [42]. Adenosine levels were increased in the arterial plasma after persistent brain ischemia in mice [43]. This increase in adenosine was associated with a subsequent cardioprotective effect and reduction of infarct size in isolated perfused mice hearts [43]. In patients undergoing coronary angiography, exogenous adenosine infusion was associated with cardioprotection, which could be transferred to reduce infarct size in perfused isolated mouse hearts [44]. While it is not considered to be cardioprotective itself, adenosine is believed to stimulate the release of cardioprotective factors. Bradykinin is not regarded as a humoral transfer factor of remote conditioning [45].

Cytokines or chemokines are considered humoral factors involved in the signal transfer pathways. Anti-inflammatory responses were associated with local ischemic conditioning [2]. In mice, plasma concentrations of interleukin-10 (IL-10) were increased after remote ischemic conditioning. Genetic knock-out of IL-10 or IL-10 receptors abolished the infarct size reduction induced by remote conditioning [46]. Stromal cell-derived factor- $1 \alpha($ SDF- $1 \alpha)$ release was observed in response to remote ischemic conditioning. Inhibition of SDF- $1 \alpha$ chemokine 4 receptors attenuated the effect of remote ischemic conditioning on infarct size [17]. Neuropeptides, including substance P and calcitonin gene-related peptide (CGRP), are considered to be causally involved in the reduction of infarct size. Substance P and CGRP receptor antagonists abrogated the effect of remote conditioning on infarct size [47]. 
Hormones, including erythropoietin and glucagon-like peptide-1 (GLP-1), were proposed as potential humoral factors. Remote ischemic conditioning in mice increased serum erythropoietin, which was in turn associated with a reduced infarct size. Exogenous administration of erythropoietin antibodies abrogated the reduction in infarct size [48]. In rats, vagus nerve activation following remote ischemic conditioning mediated a release of GLP-1. Infarct size was reduced by GLP-1 agonist. Subdiaphragmatic vagotomy or blockade of M3 muscarinic receptor abolished the effect by the GLP-1 agonist [28]. However, circulating GLP-1 minimally increased following remote conditioning [11]. The active form of GLP-1 cannot be differentiated from its inactive form [49].

Amino acids were proposed to be among the humoral factors involved in remote conditioning. In mice, genetic deletion or pharmacologic inhibition of a EGLN1 gene product, which converts $\alpha$-ketoglutarate to succinate in skeletal muscle, was shown to reduce infarct size. It was possible to transfer humoral factors from donor mice with a deletion of the EGLN1 gene to wild type recipient mice, resulting in a reduction of infarct size following occlusion/reperfusion of the coronary artery [50]. EGLN1 gene deletion leads to an increase in the expression of hypoxia-inducible factor- $1 \alpha$ (HIF- $1 \alpha)$ protein [50]. HIF-1 $\alpha$ is known as the main regulator of cytokine and hormonal signaling pathways activated following hypoxia [51]. The reduction in infarct size by remote conditioning was abolished in HIF-1 $\alpha$ heterozygous knockout mice [52]. EGLN1 gene inhibition induced by hypoxia could be one upstream regulator of HIF-1 $\alpha$ [50]. The amino acids kynurenine and glycine were identified as being associated with remote conditioning. Infarct size was reduced by infusing exogenous kynurenine and glycine in rats prior to myocardial ischemia [53]. However, the causal relationship between kynurenic acid, EGLN1, and remote conditioning remains to be established.

In rats, systemic inhibition of nitric oxide synthase abolished the effect of remote conditioning on infarct size [54,55]. However, systemic pretreatment with a nitric oxide synthase inhibitor in rabbits did not attenuate the protective effect of remote ischemic conditioning [20]. Two human studies were performed, aiming to quantify the release of nitric oxide following remote conditioning by measuring the sum of plasma nitrite and nitrate levels. A release of nitrate and nitrite was found following remote conditioning in patients undergoing elective coronary intervention [26], while no such release was observed in healthy volunteers [56].

It is now recognized that the humoral and neuronal factors interact on three distinct steps in remote ischemic conditioning: The remote stimulus, systemic level (involving transfer of signal), and target tissue. On the level of the stimulus, peripheral sensory neuronal pathways are activated, with an associated release of humoral factors and activation of the peripheral nerve [27]. On the systemic level, neuronal signals from peripheral nerves travel to the autonomic nervous centers in the brain and activate the efferent vagus nerve [27]. Vagal stimulation leads to a release of acetylcholine in both target and non-target organs and activates the muscarinic receptors, resulting in a release of humoral factors, such as GLP-1, which subsequently elicits their effects on the target organ [28]. At the target tissue level, the nervous system of the target organ is activated by the humoral factors released by the conditioning $[28,57]$. Additionally, the responses of parenchymal cells in the target organ are mediated by the humoral factors. 
Table 1. Studies on the humoral and neuronal mediators of remote ischemic conditioning.

\begin{tabular}{|c|c|c|c|c|c|}
\hline Study & Design & Animal Type & Mediator & Stimulus/Intervention & Effect \\
\hline \multicolumn{6}{|c|}{ Neuronal factors } \\
\hline Basalay 2016 [28] & Animal & Rats & Vagus nerve & Vagotomy & Abolished RIC effect \\
\hline Donato et al., 2013 [31] & Animal & Rabbits & Spinal cord & Transection at T9-10 level & Abolished RIC effect \\
\hline $\begin{array}{l}\text { Donato et al., } 2013 \text { [31] } \\
\text { Uitterdijk et al., } 2015 \text { [29] }\end{array}$ & Animal & Pig and rabbits & Vagus nerve & Electrical stimulation & Effects similar to RIC \\
\hline Lu et al., 2014 [30] & Animal & Rats & Spinal cord & Intrathecal lidocaine & $\begin{array}{c}\text { Abolished intrathecal morphine preconditioning } \\
\text { effect }\end{array}$ \\
\hline \multicolumn{6}{|c|}{ Humoral factors } \\
\hline Basalay 2016 [28] & Animal & Rats & GLP-1 & Blockade of GLP-1 receptors & Abolished cardioprotection by RIC \\
\hline $\begin{array}{l}\text { Hildebrandt et al., } 2016 \\
\text { [34] }\end{array}$ & $\begin{array}{l}\text { Human } \\
\text { to animal }\end{array}$ & $\begin{array}{l}\text { Healthy volunteers, } \\
\text { mouse heart }\end{array}$ & Unspecified & Plasma dialysate & $\begin{array}{l}\text { Could transfer cardioprotection, STAT3 is } \\
\text { activated I murine myocardium. }\end{array}$ \\
\hline Li et al., 2014 [39] & Animal & Mice & MicroRNA144 & Exogenous administration & Induced cardioprotection \\
\hline $\begin{array}{l}\text { Hepponstall et al., } 2012 \\
\text { [38] }\end{array}$ & Human & Healthy volunteers & Apolipoprotein A1 & Following RIC & Elevated in human plasma by RIC \\
\hline Hibert et al., 2013 [40] & Animal & Rat & Apolipoprotein A1 & Following RIC & Elevated in rat plasma by RIC \\
\hline $\begin{array}{l}\text { Cabrera-Fuentes et al., } \\
2015 \text { [41] }\end{array}$ & Human & $\begin{array}{l}\text { Patients undergoing } \\
\text { heart surgery }\end{array}$ & Endothelial RNase 1 & Following RIC & Elevated after RIC \\
\hline Mei et al., 2017 [42] & Animal & Rats & adenosine or bradykinin & Exogenous administration & Confers cardioprotection \\
\hline Schulte et al., 2004 [43] & Animal & Mice & adenosine & Brain ischemic conditioning & $\begin{array}{l}\text { Adenosine increase by mice brain ischemia } \\
\text { could transfer protection to mice heart }\end{array}$ \\
\hline Contractor 2016 et al. [44] & Animal & Mice & adenosine & Exogenous administration & Associated with cardioprotection \\
\hline Pedersen et al., 2011 [45] & Human & Healthy volunteers & Bradykinin & Bradykinin receptor antagonist & Had no effect on the protection by RIC \\
\hline Cai et al., 2012 [46] & Animal & Mice & IL-10 & $\begin{array}{l}\text { Genetic knock-out of IL-10 or IL-10 } \\
\text { receptor antibodies }\end{array}$ & Abolished infarct size reduction by RIC \\
\hline Davidson et al., 2013 [16] & Animal & Rats & SDF- $1 \alpha$ & Inhibiting SDF- $1 \alpha$ chemokine 4 receptor & Attenuated the infarct size-reducing effect of RIC \\
\hline Gao et al., 2007 [47] & Animal & Rats & Substance P, CGRP & Antagonist of substance P or CGRP & Abrogated the infarct size reduction \\
\hline Oba et al., 2015 [48] & Animal & Mice & Erythropoietin & $\begin{array}{l}\text { Exogenous administration of } \\
\text { erythropoietin antibodies }\end{array}$ & Abrogated the infarct size reduction \\
\hline Olenchock et al., 2016 [50] & Animal & Mice & EGLN1 gene & EGLN1 gene deletion & $\begin{array}{l}\text { reduced the infarct size and decreased } \\
\text { expression of HIF- } 1 \alpha .\end{array}$ \\
\hline Cai et al., 2013 [52] & Animal & Mice & HIF-1 $\alpha$ & HIF-1 $\alpha$ knockout & Abolished the infarct size reduction effect \\
\hline
\end{tabular}


Table 1. Cont.

\begin{tabular}{|c|c|c|c|c|c|}
\hline Study & Design & Animal Type & Mediator & Stimulus/Intervention & Effect \\
\hline \multicolumn{6}{|c|}{ Humoral factors } \\
\hline $\begin{array}{l}\text { Chao de la Barca et al., } \\
2016[53]\end{array}$ & Animal & Rats & kynurenine and glycine & Exogenous administration & Reduced myocardial infarct size \\
\hline $\begin{array}{l}\text { Donato et al., } 2016 \text { [54], } \\
\text { Shahid et al., } 2008 \text { [55] }\end{array}$ & Animal & Rats & nitric oxide & $\begin{array}{c}\text { Inhibition of systemic nitric oxide } \\
\text { synthase }\end{array}$ & Abolished the effect of RIC to reduce infarct size \\
\hline Steensrud et al., 2010 [20] & Animal & Rabbits & $\begin{array}{l}\text { adenosine } \\
\text { nitric oxide }\end{array}$ & $\begin{array}{l}\text { Femoral artery infusion of adenosine } \\
\text { Systemic nitric oxide synthase inhibitor }\end{array}$ & $\begin{array}{c}\text { Reduced myocardial infarct size } \\
\text { Did not reduce the protective effect of RIC }\end{array}$ \\
\hline $\begin{array}{l}\text { Arroyo-Martinez et al., } \\
2016[26]\end{array}$ & Human & $\begin{array}{c}\text { Patients undergoing } \\
\text { PCI }\end{array}$ & Nitrate and nitrite & Following RIC & Nitrate was released into coronary artery blood \\
\hline Lambert et al., 2016 [56] & Human & Human volunteers & Nitrate and nitrite & Following RIC & No release \\
\hline
\end{tabular}

RIC, remote ischemic conditioning; GLP-1, glucagon-like peptide-1; STAT, signal transducer and activator of transcription; IL-10, interleukin-10; SDF-1 $\alpha$, stromal cell-derived factor-1 $\alpha$; CGRP, calcitonin gene-related peptide, HIF- $1 \alpha$, hypoxia-inducible factor- $1 \alpha, \mathrm{PCI}$, percutaneous coronary intervention. 
Since protective effects were demonstrated in a number of human organs, the response to remote conditioning is believed to be systemic in nature. Ischemia/reperfusion injury was reduced by remote conditioning in the heart, lung, brain, liver, intestine, kidney, pancreas, and skeletal muscles [58]. Therefore, it can be postulated that common systemic signaling pathways are engaged in remote conditioning. However, the specific signaling pathways involved may also be organ specific. Mitochondria are regarded as common and important mediators, involved in the last steps of the signaling cascades underlying the protective pathways [2,59]. Mitochondria occupy $30 \%$ of the cytoplasmic volume of cardiomyocyte [60]. The activities of cytoprotective enzymes, such as catalase and superoxide dismutase, are low in cardiomyocytes [61]. However, signal transduction pathways have not been compared between different organs at the same time. In cardiomyocytes, the intracellular signaling seems to be species specific [2].

\subsection{Myocardial Response}

In the myocardium, protective signaling cascades are apparently activated by incoming neuronal and humoral transfer signals [25]. The cascade is activated in a receptor-independent manner or through the sarcolemmal receptors, with mitochondria believed to be the intracellular target.

The signal transduction pathways in the myocardium affected by remote ischemic conditioning are considered to be similar to the pathways activated by local ischemic conditioning. Neurohormones, such as acetylcholine, opioids, and autacoids, act on $\mathrm{G}$ protein-coupled receptors. Signaling cascades that involve protein kinases converge on the cytoskeleton and the mitochondria. Reactive oxygen species also initiate receptor-independent signals modulating cardioprotection. The intracellular signal can be transduced through three steps: (1) The reperfusion injury salvage kinase (RISK) pathway; (2) the endothelial nitric oxide synthase/protein kinase G (eNOS/PKG) pathway; and (3) the survivor activating factor enhancement (SAFE) pathway [2,25].

The upregulation of genes involved in cytoprotection (Hsp73) and those involved in the response to oxidative stress (Fabp4, Prdx4, Hadhsc) was detected by genomic profiling of the myocardium in mice $15 \mathrm{~min}$ after remote conditioning. Downregulated genes include pro-inflammatory genes, such as Dusp1, Dusp6, and Egr-1 [62]. Levels of sarcomeric Z-disk-related phosphoproteins were observed to be increased in mouse myocardium by proteomic profiling following remote ischemic conditioning [63]. In cardiac surgical patients, several cell stress-associated proteins and thioredoxin were upregulated after remote ischemic conditioning [64].

\subsection{Coronary Vascular Response}

Characteristics of ischemia/reperfusion injury of the coronary circulation include endothelial dysfunction, impaired vasomotor function, increased permeability, edema, stasis with intravascular cell aggregates, and microembolization of atherothrombotic debris. Destruction of capillaries due to hemorrhaging is one of the severe consequences of ischemia/reperfusion injury [65]. Therefore, coronary microcirculation may be the target of remote ischemic conditioning. Previous studies demonstrated improvements in coronary flow and microcirculation following ischemia/reperfusion in pigs [66], mice [34], and humans [67]. In healthy volunteers, remote conditioning stimulated nitric oxide synthase activity, improved red blood cell deformability [68], and reduced leukocyte adhesion [69]. Remote ischemic conditioning also reduced monocyte-platelet aggregation in healthy volunteers [70], in patients who underwent catheter ablation for atrial fibrillation [71], and in those who underwent coronary angiography [72].

\section{Clinical Studies Evaluating Remote Ischemic Conditioning}

Since promising expectations on the cardioprotective effect of RIPC have evolved from pre-clinical and proof-of-concept studies, researchers have focused on the clinical benefit of RIPC in patients presenting acute myocardial infarction undergoing coronary intervention or in patients undergoing cardiac surgery subjected to myocardial ischemia-reperfusion injury. Most clinical studies have proven 
the effects of RIPC on reducing post-procedural release of myocardial injury biomarkers, but RIPC did not elicit a clear benefit in terms of clinical outcomes. However, previous studies cannot completely exclude the impact of various confounding factors related to patient characteristics, concomitant medications, anesthesia, and surgery-related parameters.

\subsection{Percutaneous Coronary Intervention}

A plethora of studies have evaluated the effect of remote ischemic conditioning in patients undergoing cardiac surgery and percutaneous coronary intervention (PCI; Table 2). These investigations were motivated by the fact that cardiac surgery and PCI are exemplary models of myocardial ischemia/reperfusion injury and involve predictable periods of ischemia and restoration of perfusion. The myocardium is subjected to acute ischemia/reperfusion injury during revascularization or on initiation or weaning from cardiopulmonary bypass, upon prevailing left ventricle dysfunction and heart failure. As more patients with advanced age and co-morbidities receive cardiovascular surgery, there are increasing unmet clinical needs for novel myocardial protective strategies that would ensure better prognosis. Although the cardioprotective effects of remote ischemic conditioning have been demonstrated in preliminary animal experiments, there are significant discrepancies between the protective effects reported in pre-clinical and clinical trials, particularly when comparing the surgical conditions to the interventional environment.

In clinical studies conducted in patients with ST-segment elevated myocardial infarction (STEMI) undergoing primary PCI, remote conditioning was shown to elicit a relatively consistent reduction in markers of myocardial injury following the procedure [13,71,72]. A randomized trial reported the protective effect of four cycles of upper limb RIPC in patients with acute myocardial infarction receiving primary PCI before hospital admission [14]. RIPC increased the myocardial salvaged area at 30 days after intervention, as measured by myocardial perfusion imaging. RIPC was also effective when applied on arrival at the hospital before primary PCI [73] and even at the onset of reperfusion during coronary intervention [74].

RIPC also improved patient clinical outcomes after primary coronary intervention $[73,74]$. In patients undergoing primary PCI, four cycles of 5-min ischemia/reperfusion of the upper limb reduced the incidence of major adverse cardiac and cerebrovascular events as well as all-cause mortality compared to the control group [75]. Three cycles of intermittent ischemia in the lower limb prior to angioplasty in patients presenting with STEMI improved the combined outcome of cardiac mortality and hospitalization for heart failure during the post-procedural 2 years [76]. However, another recently reported large multicenter randomized trial on the effect of RIPC in patients with STEMI undergoing primary PCI revealed no benefit in cardiac death or hospitalization for heart failure at 12 months after PCI, compared to the control arm [77]. RIPC, therefore, seems to have beneficial effects, reducing the release of post-procedural myocardial injury biomarkers, but it is not clear whether RIPC improves clinical outcomes in patients with STEMI undergoing primary PCI. Current European Society of Cardiology guidelines for management for patients with STEMI suggests only a limited benefit of RIPC [78], while the American College of Cardiology/American Heart Association guidelines have no mention of ischemic conditioning in the management of patients with stable ischemic heart disease [79] or STEMI undergoing primary PCI [80]. 
Table 2. Clinical studies on the cardioprotective effect of remote ischemic preconditioning in patients undergoing cardiac surgery.

\begin{tabular}{|c|c|c|c|c|c|c|c|}
\hline \multirow{2}{*}{ Study } & \multirow{2}{*}{$\begin{array}{l}\text { Number, } \\
\text { RIPC/Control }\end{array}$} & \multicolumn{3}{|c|}{ RIPC Protocol } & \multirow{2}{*}{ Surgey } & \multirow{2}{*}{$\begin{array}{c}\text { Anesthetic } \\
\text { Induction/Maintenance }\end{array}$} & \multirow{2}{*}{ Results } \\
\hline & & I/R Cycles & Cuff Pressure & Limb & & & \\
\hline \multicolumn{8}{|c|}{ Cardiac biomarkers } \\
\hline Hausenloy et al., 2007 [4] & $27 / 30$ & $3 \times 5 \min$ & $200 \mathrm{mmHg}$ & Upper & CABG & $\begin{array}{l}\text { Midazolam, etomidate, } \\
\text { propofol/isoflurane, propofol }\end{array}$ & Reduced TnT during $72 \mathrm{~h}$ \\
\hline Venugopal et al., 2009 [81] & $23 / 22$ & $3 \times 5 \min$ & $200 \mathrm{mmHg}$ & Upper & $\begin{array}{l}C A B G \pm \text { aortic } \\
\text { valve surgery }\end{array}$ & $\begin{array}{l}\text { Midazolam, etomidate, } \\
\text { propofol/volatile, propofol }\end{array}$ & Reduced 72-h AUC for TnT \\
\hline Hong et al., 2010 [82] & $65 / 65$ & $4 \times 5 \min$ & $200 \mathrm{mmHg}$ & Upper & Off-pump CABG & Midazolam/sevoflurane & No difference in TnI during $72 \mathrm{~h}$ \\
\hline Young et al., 2012 [83] & $48 / 48$ & $3 \times 5 \min$ & $200 \mathrm{mmHg}$ & Upper & $\begin{array}{l}\text { High-risk cardiac } \\
\text { surgery }\end{array}$ & $\begin{array}{l}\text { Midazolam/propofol, } \\
\text { isoflurane }\end{array}$ & No difference in 6-h and 12-h TnT \\
\hline Thielmann et al., 2013 [5] & $162 / 167$ & $3 \times 5 \mathrm{~min}$ & $200 \mathrm{mmHg}$ & Upper & CABG & Isoflurane or propofol & Reduced 72-h AUC for TnI \\
\hline Kottenberg et al., 2014 [84] & $12 / 12$ & $3 \times 5 \mathrm{~min}$ & $200 \mathrm{mmHg}$ & Upper & CABG & Etomidate/propofol & No difference in 72-h AUC for TnI \\
\hline Candilio et al., 2015 [85] & $90 / 90$ & $3 \times 5 \min$ & $200 \mathrm{mmHg}$ & Upper + lower & $\begin{array}{l}\text { CABG } \pm \text { valve } \\
\text { surgery }\end{array}$ & $\begin{array}{l}\text { Midazolam, etomidate, } \\
\text { propofol/isoflurane, } \\
\text { sevoflurane, propofol }\end{array}$ & Reduced 72-h AUC for TnT \\
\hline Walsh et al., 2016 [86] & $128 / 130$ & $3 \times 5 \min$ & $300 \mathrm{mmHg}$ & Lower & Cardiac surgery & Volatile, propofol & No difference in 24-h CK-MB \\
\hline Pinaud et al., 2016 [87] & $50 / 49$ & $3 \times 5 \min$ & $200 \mathrm{mmHg}$ & Upper & AVR & $\begin{array}{l}\text { Propofol/isoflurane, } \\
\text { sevoflurane, propofol }\end{array}$ & No difference in 72-h AUC for TnI \\
\hline Song et al., 2017 [88] & $36 / 36$ & $3 \times 5 \min$ & $300 \mathrm{mmHg}$ & Upper & AVR & Midazolam/sevoflurane & $\begin{array}{c}\text { No difference in 24-h AUC for } \\
\text { CK-MB and TnT }\end{array}$ \\
\hline Zadeh et al., 2017 [89] & $14 / 14$ & $3 \times 5 \mathrm{~min}$ & $200 \mathrm{mmHg}$ & Upper & CABG & $\begin{array}{l}\text { Midazolam, } \\
\text { ketamine/isoflurane }\end{array}$ & Reduced 6-h and 24-h TnI \\
\hline Wang et al., 2019 [90] & $33 / 32$ & $4 \times 5 \min$ & $\mathrm{SBP}+40 \mathrm{mmHg}$ & Upper & Off-pump CABG & $\begin{array}{l}\text { Midazolam, } \\
\text { etomidate/sevoflurane }\end{array}$ & Reduced 120-h TnT \\
\hline Jin et al., 2019 [91] & $121 / 120$ & $2 \times 5 \min$ & $200 \mathrm{mmHg}$ & Upper + lower & $\begin{array}{l}\text { Valve replacement } \\
\text { surgery }\end{array}$ & Imidazole valium, propofol & $\begin{array}{l}\text { Reduced } 6-\mathrm{h} \text { and } 24-\mathrm{h} \\
\text { post-CPB TnT }\end{array}$ \\
\hline
\end{tabular}


Table 2. Cont

\begin{tabular}{|c|c|c|c|c|c|c|c|}
\hline \multirow{2}{*}{ Study } & \multirow{2}{*}{$\begin{array}{l}\text { Number, } \\
\text { RIPC/Control }\end{array}$} & \multicolumn{3}{|c|}{ RIPC Protocol } & \multirow{2}{*}{ Surgey } & \multirow{2}{*}{$\begin{array}{c}\text { Anesthetic } \\
\text { Induction/Maintenance }\end{array}$} & \multirow{2}{*}{ Results } \\
\hline & & I/R Cycles & Cuff Pressure & Limb & & & \\
\hline \multicolumn{8}{|c|}{ Clinical outcomes } \\
\hline Thielmann et al., 2013 [5] & $162 / 167$ & $3 \times 5 \min$ & $200 \mathrm{mmHg}$ & Upper & CABG & Isoflurane or propofol & Reduced all-cause mortality at $1.5 \mathrm{y}$ \\
\hline Candilio et al., 2015 [85] & $90 / 90$ & $3 \times 5 \mathrm{~min}$ & $200 \mathrm{mmHg}$ & Upper + lower & $\begin{array}{l}\mathrm{CABG} \pm \text { valve } \\
\text { surgery }\end{array}$ & $\begin{array}{l}\text { Midazolam, etomidate, } \\
\text { propofol / isoflurane, } \\
\text { sevoflurane, propofol }\end{array}$ & $\begin{array}{l}\text { Reduced AKI, AF, and length of } \\
\text { ICU stay }\end{array}$ \\
\hline Meybohm et al., 2015 [92] & $692 / 693$ & $4 \times 5 \min$ & $200 \mathrm{mmHg}$ & Upper & Cardiac surgery & Propofol & $\begin{array}{l}\text { No difference in } \\
\text { composite outcome }\end{array}$ \\
\hline Hausenloy et al., 2015 [93] & $801 / 811$ & $4 \times 5 \min$ & $200 \mathrm{mmHg}$ & Upper & $\begin{array}{l}\mathrm{CABG} \pm \text { valve } \\
\text { surgery }\end{array}$ & Volatile, propofol & $\begin{array}{l}\text { No difference in } \\
\text { composite outcome }\end{array}$ \\
\hline Coverdale et al., 2018 [94] & $213 / 215$ & $3 \times 5 \mathrm{~min}$ & $200 \mathrm{mmHg}$ & Upper & $\begin{array}{l}\text { High-risk } \\
\text { cardiovascular } \\
\text { surgery }\end{array}$ & $\begin{array}{l}\text { Midazolam, propofol, } \\
\text { etomidate / desflurane, } \\
\text { sevoflurane, propofol }\end{array}$ & $\begin{array}{l}\text { No difference in } \\
\text { composite outcome }\end{array}$ \\
\hline Jin et al., 2019 [91] & $121 / 120$ & $2 \times 5 \mathrm{~min}$ & $200 \mathrm{mmHg}$ & Upper + lower & $\begin{array}{l}\text { Valve replacement } \\
\text { surgery }\end{array}$ & Imidazole valium, propofol & $\begin{array}{l}\text { Reduced acute lung injury, } \\
\text { and length of ICU and hospital stay }\end{array}$ \\
\hline
\end{tabular}

$\mathrm{AF}$, atrial fibrillation; AKI, acute kidney injury; AUC: area under curve; AVR, aortic valve replacement; CABG, coronary artery bypass graft; CK-MB, creatine kinase-myocardial band; ICU, intensive care unit; I/R, ischemia/reperfusion; RIPC, remote ischemic preconditioning; TnI, troponin I; TnT, troponin T. 


\subsection{Cardiac Surgery}

Perioperative application of remote ischemic conditioning did not consistently elicit beneficial effects in terms of target organ protection $[5,85,92,93,95,96]$, in contrast to peri-procedural applications, such as primary PCI or catheter ablation [13,71,72]. In the first adult study of cardiac surgery [4], three cycles of 5-min ischemia and 5-min reperfusion of the upper limb using a pressure cuff inflated to $200 \mathrm{mmHg}$ reduced troponin-T release during $48 \mathrm{~h}$ after coronary artery bypass graft (CABG) surgery. Several subsequent studies have reported favorable outcomes following this landmark trial. Similarly, RIPC protocol also reduced the postoperative release of cardiac troponin-I within $72 \mathrm{~h}$ after CABG and reduced all-cause mortality in the 1.5 years following surgery [5]. Two cycles of simultaneous upper and lower limb ischemia/reperfusion reduced 72-h postoperative troponin- $\mathrm{T}$ concentrations in patients undergoing $C A B G$ and/or heart valve surgery, as compared to the control group [85]. However, not all studies evaluating RIPC during cardiac surgery demonstrated favorable results and a reduction in cardiac biomarkers. Hong et al. did not observe any reduction in the postoperative release of troponin-I during $72 \mathrm{~h}$ following the application of four cycles of RIPC in patients undergoing off-pump CABG [82]. In patients with concentric myocardial hypertrophy undergoing aortic valve replacement, three cycles of upper limb RIPC did not affect the 24-h area under the curve for creatine kinase-myocardial band or troponin-T levels following the surgery [88]. Although some inconsistent results have been presented, a recent meta-analysis reported the protective effects of RIPC, as measured by cardiac biomarkers. After pooling the results of 30 trials of CABG or valve surgery, RIPC was found to reduce postoperative troponin release compared to the control arm [97]. Moreover, RIPC ameliorated sinus rhythm restoration up to 1 year after surgery and reduced postoperative markers of systemic inflammation in patients undergoing Cox maze radiofrequency ablation with concomitant mitral valve surgery [98].

However, despite the reported protective effects on the surrogate markers of myocardial injury, several large-scale multicenter studies did not find any beneficial effect of RIPC on clinical outcomes, including the rate of major adverse cardiac events and mortality, as compared to the control group $[92,93,95,96]$. Given these negative clinical studies, a recent Cochrane review concluded that there is no evidence of a treatment effect of RIPC on clinical outcomes when assessed as a composite endpoint (including all-cause mortality, myocardial infarction, or stroke) in patients undergoing CABG and/or valve surgery, although RIPC did reduce postoperative troponin-T release at $72 \mathrm{~h}$ after surgery [99]. A currently available position paper by the European Society of Cardiology Joint Working Group reported that RIPC may attenuate perioperative myocardial injury without a significant benefit on clinical outcomes in patients undergoing CABG surgery [100], but the American College of Cardiology/American Heart Association guideline did not mention it in the management of patients with valvular heart disease [101].

Unsuccessful translation of the protective effects observed in studies in healthy animals into clinical trials was attributed to the underlying risk factors present in patients and to the concomitant use of potentially cardioprotective agents [102]. Notably, the use of the anesthetic agent propofol, which was used in the majority of patients in the aforementioned phase III trials $[92,93,95]$, was proposed to be a major confounding factor, potentially interrupting the RIPC process $[5,87,103,104]$. During CABG surgery, three cycles of RIPC in the upper limb reduced postoperative release of cardiac troponin-I under isoflurane/sufentanil anesthesia but did not have any effect when used in propofol/sufentanil anesthesia in patients with ischemic heart disease [103]. Propofol was suggested to abrogate the cardioprotective effect of RIPC in anesthetized patients. A previous study demonstrated that propofol interferes with the transduction of the cardioprotective signal of RIPC in patients with ischemic heart disease by inhibiting the phosphorylation of signal transducer and activator of transcription (STAT5) [84]. In a subsequent randomized controlled study where propofol was excluded from the anesthetic regimen, RIPC reduced postoperative troponin I release during $72 \mathrm{~h}$ post-surgery, and a decreased rate of all-cause and cardiac mortality was observed during the 1.5-year follow-up [5]. This beneficial effect was sustained in the long-term analysis, with patients followed up for a median duration of 5 year (up to 9 year) following 
CABG surgery [104]. In small randomized trials in patients undergoing on- [89] or off-pump CABG surgery [90] without propofol, RIPC was reported to reduce postoperative release of cardiac troponins.

Volatile anesthetic agents were also suggested to exhibit protective effects and their use could be a confounding factor in the evaluation of the effect of RIPC. This organ protective effect is supported by a meta-analysis that showed a beneficial effect of volatile anesthesia on survival after cardiac surgery by pooling the data from 38 trials after excluding studies with ischemic or remote ischemic conditioning [105]. A Bayesian network meta-analysis of 55 trials also demonstrated the beneficial effect of RIPC during cardiac surgery on short- and long-term survival with the use of volatile anesthetic agents [106]. Xie et al. reported a possible protective effect of volatile anesthetic agents based on a meta-analysis of 30 trials evaluating a total population of 7036 patients undergoing cardiac surgery. They concluded that RIPC significantly reduced postoperative markers of myocardial injury but did not reduce the incidence of acute myocardial infarction or acute kidney injury, and had no effect on mortality [97]. However, RIPC reduced the incidence of acute kidney injury and mortality in the subset of patients who were anesthetized using volatile agents.

However, in these two meta-analyses [82,93], the propofol group was defined to include only patients who were never exposed to any volatile agent during the surgery, while the volatile group included patients with any exposure to volatile agents, regardless of the dose and timing, even if added to a regimen involving propofol. Therefore, it is difficult to completely exclude the potential residual effect of propofol in the volatile group in these analyses. Considering all the previous study results and limitations, the Cochrane review could not conclusively confirm or rule out propofol as a confounding factor in the assessment of RIPC effectiveness in cardiac surgical patients, mainly due to the limited number of studies and the lack of a control for confounding variables, such as co-morbidities and concomitant-medications $[99,107]$. Moreover, these findings should be interpreted with caution, considering the risk of bias, including the number of patients who received each anesthetic [108].

A recent study by Behmenburg et al. explored the influence of various anesthetic regimens used during RIPC on myocardial protective effects in an in vivo animal study [109]. The authors compared three anesthetic regimens (pentobarbital alone, sevoflurane combined with remifentanil, and propofol combined with remifentanil) on the effect of four cycles of bilateral hind limb RIPC followed by induction of left anterior descending regional myocardial ischemia/reperfusion injury. Myocardial protective effects of RIPC were preserved under pentobarbital- and sevoflurane-based anesthesia, while the effect of RIPC was abrogated during propofol anesthesia. A subsequent randomized clinical trial compared sevoflurane and propofol, the two most frequently used anesthetics, combined with continuous infusion of remifentanil in patients undergoing cardiac surgery and receiving four cycles of upper limb RIPC [110]. However, in that study, both anesthetics hindered the myocardial protective effects of limb RIPC, whereas the control group that received RIPC preoperatively in an awake state and underwent cardiac surgery did show a reduction in infarct size in the rat myocardium perfused with dialysate from the preconditioned patients. This study considered patient factors (such as comorbidities and concomitant medications), the effect of general anesthesia-related interference on the neural signaling pathway, and the concentration of propofol infused during the study period as confounding factors.

\subsection{Other Potential Confounding Factors for the Effect of RIPC}

Other confounding factors that may contribute to the no effects of RIPC on cardioprotection in cardiac surgery patients include nitrates $[75,98]$ and beta-adrenergic blocking agents [110-114]. However, a retrospective analysis of a randomized trial did not find any significant associations between age, gender, beta-adrenergic receptor blocking agents, angiotensin converting enzyme inhibitors, angiotensin receptor blockers, intraoperative nitroglycerine, and RIPC-induced cardioprotection during CABG [115]. For patients undergoing PCI, prior episodes of angina or ischemia, door-to-balloon time, and any interaction or delay between them would also be important confounders. 
The age of subjects receiving RIPC could also be a major confounding factor. Compared to the young adult rat, the heart of a middle-aged rat exhibited a blunted response to ischemic conditioning, while the aged rat heart could not be preconditioned through mechanical or pharmacological methods [116]. One major difference between experimental conditions and clinical trials is the age of subjects receiving RIPC. Response to ischemic conditioning in aging hearts or elderly patients was reported to be resistant to the protective effect of RIPC in several previous studies [117-119]. RIPC reduced the length of ICU stay and ventilation time, as well as postoperative serum troponin $\mathrm{T}$ levels in children (mean age of 11 months) undergoing heart surgery for congenital defects using cardiopulmonary bypass [120]. In this study, the anesthetic agents used included sevoflurane, midazolam, fentanyl, and sufentanil but not propofol. In contrast to these reports, a post-hoc subgroup analysis of a randomized controlled trial showed that the cardioprotective effect of RIPC was not different between patients older or younger than 70 years [119]. However, this post-hoc analysis had a limited sample size of only 139 patients, putting the study power in question.

Moreover, disappointing results were obtained from the analysis of RIPC effects on mitigating ischemia/reperfusion injury in patients with type 2 diabetes, suggesting the potential role of diabetes as a confounding factor [118,121]. RIPC failed to reduce infarct size in obese rats with type 2 diabetes compared to lean rats [122]. An underlying cause for this effect could involve the association of diabetes with impaired humoral communication of cardioprotective signals in cardiomyocytes subjected to hypoxia-reoxygenation [122]. Diabetes also modifies the myocardial response to ischemic conditioning and interrupts intracellular signaling, thus potentially obscuring the cardioprotective effects of ischemic conditioning [121].

Treatment with anti-diabetic agents can also impact on the cardioprotective action of ischemic conditioning. Blood glucose-lowering agents can modulate intracellular signaling pathways within the heart, which may modulate the protective efficacy of RIPC [123]. Since 2011, the U.S. Food and Drug Administration has recommended that companies developing new drugs for type 2 diabetes provide the evidence that the drug will not increase the risk of cardiovascular events. Since then, most of the new anti-diabetic drugs have favorable aspects regarding myocardial protection [124]. However, the effect of a RIPC-lowering postoperative cardiac biomarker was abolished in sulphonylurea-treated diabetic patients undergoing coronary artery surgery under isoflurane anesthesia [125].

Diabetic neuropathy may impair the effect of RIPC through a suspected interruption in the neuronal pathways [32]. While there was no transferrable protective effect of RIPC from patients with diabetic peripheral neuropathy, the protective effect was transferrable from non-diabetic subjects or diabetics without peripheral neuropathy. Therefore, it has been suggested that RIPC should be repeated over a prolonged period (several days to weeks) to overcome the unresponsiveness of diabetic subjects to ischemic conditioning [126].

Other confounders during cardiac surgery include the use and duration of cardioplegia, which may affect the extent of myocardial injury and might also impact on signal transduction pathways [127]. Hypothermia, advances in intraoperative myocardial protective strategies, and improvement of surgical techniques could be confounding factors because they may reduce perioperative myocardial injury as well as postoperative mortality [7]. Moreover, cross-clamp versus all bypasses during one clamp, types of cardioplegic solutions, and delayed or prolonged weaning from CPB also can be important confounders during cardiac surgery, which remain as subjects for further investigation.

\subsection{Future Study Directions}

Recently, failure of the translation of pre-clinical experimental effects into clinical patient outcomes has been attributed to several newly discovered key factors. Multi-target and multi-strategic trial designs are suggested as potential approaches to overcome the multifaceted nature of myocardial ischemia/reperfusion injury $[128,129]$. Although myocardial injury biomarkers are surrogates for serious morbidity and mortality after cardiac surgery and PCI, clinical outcomes are multifactorial and attributable not only to regional or global ischemia/reperfusion injury but more substantially to 
underlying comorbidities, perioperative complications, inconsistent procedural strategies, and large inter-individual variability.

The ultimate goal of any cardioprotective strategy is to improve clinical outcomes. However, appropriate measures of clinical outcomes are challenging due to variations in study conditions. Consequently, cardioprotective effects of RIPC should be evaluated using multitarget strategies and optimized measures of composite outcomes in future studies considering the complex clinical circumstances of cardiac surgical patients.

Author Contributions: The authors of this manuscript have contributed in the following manners: Conceptualization, W.H.K.; writing—original draft preparation, Y.J.C., W.H.K.; writing—review and editing, Y.J.C., W.H.K. All authors approve the submitted version of this manuscript and agree to be personally accountable for their individual contributions and for ensuring that questions related to the accuracy or integrity of the work are appropriately investigated, resolved, and documented in the literature.

Funding: This research received no external funding.

Conflicts of Interest: The authors declare no conflict of interest.

\section{Abbreviations}

$\begin{array}{ll}\text { AF } & \text { Atrial fibrillation } \\ \text { AKI } & \text { Acute Kidney Injury } \\ \text { AUC } & \text { Area under curve } \\ \text { AVR } & \text { Aortic valve replacement } \\ \text { CABG } & \text { Coronary artery bypass graft } \\ \text { CGRP } & \text { Calcitonin gene-related peptide } \\ \text { CK-MB } & \text { Creatine kinase-myocardial band } \\ \text { eNOS } & \text { Endothelial nitric oxide synthase } \\ \text { GLP-1 } & \text { Glucagon-Like Peptide-1 } \\ \text { HIF-1 } \alpha & \text { Hypoxia-Inducible Factor-1 } \alpha \\ \text { ICU } & \text { Intensive care unit } \\ \text { I/R } & \text { Ischemia/reperfusion } \\ \text { PCI } & \text { Percutaneous Coronary Intervention } \\ \text { PKG } & \text { Protein Kinase G } \\ \text { RIPC } & \text { Remote Ischemic Preconditioning } \\ \text { SAFE } & \text { Survivor Activating Factor Enhancement } \\ \text { SDF-1 } \alpha & \text { Stromal Cell-Derived Factor-1 } \alpha \\ \text { STAT-5 } & \text { Signal Transducer and Activator of transcription-5 } \\ \text { STEMI } & \text { ST-segment Elevated Myocardial Infarction } \\ \text { TnI } & \text { Troponin I } \\ \text { TnT } & \text { Troponin T } \\ & \end{array}$

\section{References}

1. Ibanez, B.; Heusch, G.; Ovize, M.; Van de Werf, F. Evolving therapies for myocardial ischemia/reperfusion injury. J. Am. Coll. Cardiol. 2015, 65, 1454-1471. [CrossRef] [PubMed]

2. Heusch, G. Molecular basis of cardioprotection: Signal transduction in ischemic pre-, post-, and remote conditioning. Circ. Res. 2015, 116, 674-699. [CrossRef] [PubMed]

3. Przyklenk, K.; Bauer, B.; Ovize, M.; Kloner, R.A.; Whittaker, P. Regional ischemic 'preconditioning' protects remote virgin myocardium from subsequent sustained coronary occlusion. Circulation 1993, 87, 893-899. [CrossRef] [PubMed]

4. Hausenloy, D.J.; Mwamure, P.K.; Venugopal, V.; Harris, J.; Barnard, M.; Grundy, E.; Ashley, E.; Vichare, S.; Di Salvo, C.; Kolvekar, S.; et al. Effect of remote ischaemic preconditioning on myocardial injury in patients undergoing coronary artery bypass graft surgery: A randomised controlled trial. Lancet 2007, 370, 575-579. [CrossRef] 
5. Thielmann, M.; Kottenberg, E.; Kleinbongard, P.; Wendt, D.; Gedik, N.; Pasa, S.; Price, V.; Tsagakis, K.; Neuhauser, M.; Peters, J.; et al. Cardioprotective and prognostic effects of remote ischaemic preconditioning in patients undergoing coronary artery bypass surgery: A single-centre randomised, double-blind, controlled trial. Lancet 2013, 382, 597-604. [CrossRef]

6. Heusch, G.; Botker, H.E.; Przyklenk, K.; Redington, A.; Yellon, D. Remote ischemic conditioning. J. Am. Coll. Cardiol. 2015, 65, 177-195. [CrossRef]

7. Hausenloy, D.J.; Yellon, D.M. Ischaemic conditioning and reperfusion injury. Nat. Rev. Cardiol. 2016, 13, $193-209$. [CrossRef]

8. Basalay, M.; Barsukevich, V.; Mastitskaya, S.; Mrochek, A.; Pernow, J.; Sjoquist, P.O.; Ackland, G.L.; Gourine, A.V.; Gourine, A. Remote ischaemic pre- and delayed postconditioning-Similar degree of cardioprotection but distinct mechanisms. Exp. Physiol. 2012, 97, 908-917. [CrossRef]

9. Johnsen, J.; Pryds, K.; Salman, R.; Lofgren, B.; Kristiansen, S.B.; Botker, H.E. The remote ischemic preconditioning algorithm: Effect of number of cycles, cycle duration and effector organ mass on efficacy of protection. Basic Res. Cardiol. 2016, 111, 10. [CrossRef]

10. Whittaker, P.; Przyklenk, K. From ischemic conditioning to 'hyperconditioning': Clinical phenomenon and basic science opportunity. Dose-Response 2014, 12, 650-663. [CrossRef] [PubMed]

11. Heusch, G. Remote ischemic conditioning: The enigmatic transfer of protection. Cardiovasc. Res. 2017, 113, 1-2. [CrossRef] [PubMed]

12. Kharbanda, R.K.; Mortensen, U.M.; White, P.A.; Kristiansen, S.B.; Schmidt, M.R.; Hoschtitzky, J.A.; Vogel, M.; Sorensen, K.; Redington, A.N.; MacAllister, R. Transient limb ischemia induces remote ischemic preconditioning in vivo. Circulation 2002, 106, 2881-2883. [CrossRef] [PubMed]

13. Loukogeorgakis, S.P.; Panagiotidou, A.T.; Broadhead, M.W.; Donald, A.; Deanfield, J.E.; MacAllister, R.J. Remote ischemic preconditioning provides early and late protection against endothelial ischemia-reperfusion injury in humans: Role of the autonomic nervous system. J. Am. Coll. Cardiol. 2005, 46, 450-456. [CrossRef] [PubMed]

14. Botker, H.E.; Kharbanda, R.; Schmidt, M.R.; Bottcher, M.; Kaltoft, A.K.; Terkelsen, C.J.; Munk, K.; Andersen, N.H.; Hansen, T.M.; Trautner, S.; et al. Remote ischaemic conditioning before hospital admission, as a complement to angioplasty, and effect on myocardial salvage in patients with acute myocardial infarction: A randomised trial. Lancet 2010, 375, 727-734. [CrossRef]

15. Zarbock, A.; Schmidt, C.; Van Aken, H.; Wempe, C.; Martens, S.; Zahn, P.K.; Wolf, B.; Goebel, U.; Schwer, C.I.; Rosenberger, P.; et al. Effect of remote ischemic preconditioning on kidney injury among high-risk patients undergoing cardiac surgery: A randomized clinical trial. JAMA 2015, 313, 2133-2141. [CrossRef]

16. Davidson, S.M.; Selvaraj, P.; He, D.; Boi-Doku, C.; Yellon, R.L.; Vicencio, J.M.; Yellon, D.M. Remote ischaemic preconditioning involves signalling through the SDF-1alpha/CXCR4 signalling axis. Basic Res. Cardiol. 2013, 108, 377. [CrossRef] [PubMed]

17. Heyman, S.N.; Leibowitz, D.; Mor-Yosef Levi, I.; Liberman, A.; Eisenkraft, A.; Alcalai, R.; Khamaisi, M.; Rosenberger, C. Adaptive response to hypoxia and remote ischaemia pre-conditioning: A new hypoxia-inducible factors era in clinical medicine. Acta Physiol. 2016, 216, 395-406. [CrossRef]

18. Rassaf, T.; Totzeck, M.; Hendgen-Cotta, U.B.; Shiva, S.; Heusch, G.; Kelm, M. Circulating nitrite contributes to cardioprotection by remote ischemic preconditioning. Circ. Res. 2014, 114, 1601-1610. [CrossRef] [PubMed]

19. Skyschally, A.; Gent, S.; Amanakis, G.; Schulte, C.; Kleinbongard, P.; Heusch, G. Across-species transfer of protection by remote ischemic preconditioning with species-specific myocardial signal transduction by reperfusion injury salvage kinase and survival activating factor enhancement pathways. Circ. Res. 2015, 117, 279-288. [CrossRef]

20. Steensrud, T.; Li, J.; Dai, X.; Manlhiot, C.; Kharbanda, R.K.; Tropak, M.; Redington, A. Pretreatment with the nitric oxide donor SNAP or nerve transection blocks humoral preconditioning by remote limb ischemia or intra-arterial adenosine. Am. J. Physiol. Heart Circ. Physiol. 2010, 299, H1598-H1603. [CrossRef]

21. Jones, W.K.; Fan, G.C.; Liao, S.; Zhang, J.M.; Wang, Y.; Weintraub, N.L.; Kranias, E.G.; Schultz, J.E.; Lorenz, J.; Ren, X. Peripheral nociception associated with surgical incision elicits remote nonischemic cardioprotection via neurogenic activation of protein kinase C signaling. Circulation 2009, 120, S1-S9. [CrossRef]

22. Liem, D.A.; Verdouw, P.D.; Ploeg, H.; Kazim, S.; Duncker, D.J. Sites of action of adenosine in interorgan preconditioning of the heart. Am. J. Physiol. Heart Circ. Physiol. 2002, 283, H29-H37. [CrossRef] [PubMed] 
23. Gross, E.R.; Hsu, A.K.; Urban, T.J.; Mochly-Rosen, D.; Gross, G.J. Nociceptive-induced myocardial remote conditioning is mediated by neuronal gamma protein kinase C. Basic Res. Cardiol. 2013, 108, 381. [CrossRef] [PubMed]

24. Redington, K.L.; Disenhouse, T.; Strantzas, S.C.; Gladstone, R.; Wei, C.; Tropak, M.B.; Dai, X.; Manlhiot, C.; Li, J.; Redington, A.N. Remote cardioprotection by direct peripheral nerve stimulation and topical capsaicin is mediated by circulating humoral factors. Basic Res. Cardiol. 2012, 107, 241. [CrossRef] [PubMed]

25. Kleinbongard, P.; Heusch, G. Extracellular signalling molecules in the ischaemic/reperfused heart-Druggable and translatable for cardioprotection? Br. J. Pharmacol. 2015, 172, 2010-2025. [CrossRef]

26. Arroyo-Martinez, E.A.; Meaney, A.; Gutierrez-Salmean, G.; Rivera-Capello, J.M.; Gonzalez-Coronado, V.; Alcocer-Chauvet, A.; Castillo, G.; Najera, N.; Ceballos, G.; Meaney, E. Is local nitric oxide availability responsible for myocardial salvage after remote preconditioning? Arq. Bras. Cardiol. 2016, 107, $154-162$. [CrossRef] [PubMed]

27. Gourine, A.; Gourine, A.V. Neural mechanisms of cardioprotection. Physiology 2014, 29, 133-140. [CrossRef]

28. Basalay, M.V.; Mastitskaya, S.; Mrochek, A.; Ackland, G.L.; Del Arroyo, A.G.; Sanchez, J.; Sjoquist, P.O.; Pernow, J.; Gourine, A.V.; Gourine, A. Glucagon-like peptide-1 (GLP-1) mediates cardioprotection by remote ischaemic conditioning. Cardiovasc. Res. 2016, 112, 669-676. [CrossRef] [PubMed]

29. Uitterdijk, A.; Yetgin, T.; te Lintel Hekkert, M.; Sneep, S.; Krabbendam-Peters, I.; van Beusekom, H.M.; Fischer, T.M.; Cornelussen, R.N.; Manintveld, O.C.; Merkus, D.; et al. Vagal nerve stimulation started just prior to reperfusion limits infarct size and no-reflow. Basic Res. Cardiol. 2015, 110, 508. [CrossRef]

30. Lu, Y.; Wong, G.T.; Zhang, Y.; Hu, J.; Dong, C. Remote intrathecal morphine preconditioning is ineffective in the presence of neuraxial blockade with lidocaine. Kaohsiung J. Med. Sci. 2014, 30, 68-72. [CrossRef]

31. Donato, M.; Buchholz, B.; Rodriguez, M.; Perez, V.; Inserte, J.; Garcia-Dorado, D.; Gelpi, R.J. Role of the parasympathetic nervous system in cardioprotection by remote hindlimb ischaemic preconditioning. Exp. Physiol. 2013, 98, 425-434. [CrossRef]

32. Jensen, R.V.; Stottrup, N.B.; Kristiansen, S.B.; Botker, H.E. Release of a humoral circulating cardioprotective factor by remote ischemic preconditioning is dependent on preserved neural pathways in diabetic patients. Basic Res. Cardiol. 2012, 107, 285. [CrossRef] [PubMed]

33. Dickson, E.W.; Reinhardt, C.P.; Renzi, F.P.; Becker, R.C.; Porcaro, W.A.; Heard, S.O. Ischemic preconditioning may be transferable via whole blood transfusion: Preliminary evidence. J. Thromb. Thrombolysis 1999, 8, 123-129. [CrossRef] [PubMed]

34. Hildebrandt, H.A.; Kreienkamp, V.; Gent, S.; Kahlert, P.; Heusch, G.; Kleinbongard, P. Kinetics and signal activation properties of circulating factor(s) from healthy volunteers undergoing remote ischemic pre-conditioning. JACC Basic Transl. Sci. 2016, 1, 3-13. [CrossRef] [PubMed]

35. Shimizu, M.; Tropak, M.; Diaz, R.J.; Suto, F.; Surendra, H.; Kuzmin, E.; Li, J.; Gross, G.; Wilson, G.J.; Callahan, J.; et al. Transient limb ischaemia remotely preconditions through a humoral mechanism acting directly on the myocardium: Evidence suggesting cross-species protection. Clin. Sci. 2009, 117, 191-200. [CrossRef] [PubMed]

36. Dickson, E.W.; Blehar, D.J.; Carraway, R.E.; Heard, S.O.; Steinberg, G.; Przyklenk, K. Naloxone blocks transferred preconditioning in isolated rabbit hearts. J. Mol. Cell. Cardiol. 2001, 33, 1751-1756. [CrossRef] [PubMed]

37. Serejo, F.C.; Rodrigues, L.F.; da Silva Tavares, K.C.; de Carvalho, A.C.; Nascimento, J.H. Cardioprotective properties of humoral factors released from rat hearts subject to ischemic preconditioning. J. Cardiovasc. Pharmacol. 2007, 49, 214-220. [CrossRef] [PubMed]

38. Hepponstall, M.; Ignjatovic, V.; Binos, S.; Monagle, P.; Jones, B.; Cheung, M.H.; d’Udekem, Y.; Konstantinov, I.E. Remote ischemic preconditioning (RIPC) modifies plasma proteome in humans. PLoS ONE 2012, 7, e48284. [CrossRef] [PubMed]

39. Li, J.; Rohailla, S.; Gelber, N.; Rutka, J.; Sabah, N.; Gladstone, R.A.; Wei, C.; Hu, P.; Kharbanda, R.K.; Redington, A.N. MicroRNA-144 is a circulating effector of remote ischemic preconditioning. Basic Res. Cardiol. 2014, 109, 423. [CrossRef] [PubMed]

40. Hibert, P.; Prunier-Mirebeau, D.; Beseme, O.; Chwastyniak, M.; Tamareille, S.; Lamon, D.; Furber, A.; Pinet, F.; Prunier, F. Apolipoprotein a-I is a potential mediator of remote ischemic preconditioning. PLoS ONE 2013, 8, e77211. [CrossRef] 
41. Cabrera-Fuentes, H.A.; Niemann, B.; Grieshaber, P.; Wollbrueck, M.; Gehron, J.; Preissner, K.T.; Boning, A. RNase1 as a potential mediator of remote ischaemic preconditioning for cardioprotectiondagger. Eur. J. Cardiothorac. Surg. 2015, 48, 732-737. [CrossRef] [PubMed]

42. Mei, B.; Li, W.; Cheng, X.; Liu, X.; Gu, E.; Zhang, Y. Activating mu-opioid receptors in the spinal cord mediates the cardioprotective effect of remote preconditioning of trauma. Cardiol. J. 2017, 24, 314-323. [CrossRef] [PubMed]

43. Schulte, G.; Sommerschild, H.; Yang, J.; Tokuno, S.; Goiny, M.; Lovdahl, C.; Johansson, B.; Fredholm, B.B.; Valen, G. Adenosine a receptors are necessary for protection of the murine heart by remote, delayed adaptation to ischaemia. Acta Physiol. Scand. 2004, 182, 133-143. [CrossRef] [PubMed]

44. Contractor, H.; Lie, R.H.; Cunnington, C.; Li, J.; Stottrup, N.B.; Manlhiot, C.; Botker, H.E.; Schmidt, M.R.; Forfar, J.C.; Ashrafian, H.; et al. Adenosine receptor activation in the "trigger" limb of remote pre-conditioning mediates human endothelial conditioning and release of circulating cardioprotective factor(s). JACC Basic Transl. Sci. 2016, 1, 461-471. [CrossRef] [PubMed]

45. Pedersen, C.M.; Schmidt, M.R.; Barnes, G.; Botker, H.E.; Kharbanda, R.K.; Newby, D.E.; Cruden, N.L. Bradykinin does not mediate remote ischaemic preconditioning or ischaemia-reperfusion injury in vivo in man. Heart 2011, 97, 1857-1861. [CrossRef]

46. Cai, Z.P.; Parajuli, N.; Zheng, X.; Becker, L. Remote ischemic preconditioning confers late protection against myocardial ischemia-reperfusion injury in mice by upregulating interleukin-10. Basic Res. Cardiol. 2012, 107, 277. [CrossRef]

47. Gao, J.; Fu, W.; Jin, Z.; Yu, X. Acupuncture pretreatment protects heart from injury in rats with myocardial ischemia and reperfusion via inhibition of the beta (1)-adrenoceptor signaling pathway. Life Sci. 2007, 80, 1484-1489. [CrossRef]

48. Oba, T.; Yasukawa, H.; Nagata, T.; Kyogoku, S.; Minami, T.; Nishihara, M.; Ohshima, H.; Mawatari, K.; Nohara, S.; Takahashi, J.; et al. Renal nerve-mediated erythropoietin release confers cardioprotection during remote ischemic preconditioning. Circ. J. 2015, 79, 1557-1567. [CrossRef]

49. Holst, J.J. The physiology of glucagon-like peptide 1. Physiol. Rev. 2007, 87, 1409-1439. [CrossRef]

50. Olenchock, B.A.; Moslehi, J.; Baik, A.H.; Davidson, S.M.; Williams, J.; Gibson, W.J.; Chakraborty, A.A.; Pierce, K.A.; Miller, C.M.; Hanse, E.A.; et al. EGLN1 inhibition and rerouting of alpha-ketoglutarate suffice for remote ischemic protection. Cell 2016, 164, 884-895. [CrossRef]

51. Martin-Puig, S.; Tello, D.; Aragones, J. Novel perspectives on the PHD-HIF oxygen sensing pathway in cardioprotection mediated by IPC and RIPC. Front. Physiol. 2015, 6, 137. [CrossRef] [PubMed]

52. Cai, Z.; Luo, W.; Zhan, H.; Semenza, G.L. Hypoxia-inducible factor 1 is required for remote ischemic preconditioning of the heart. Proc. Natl. Acad. Sci. USA 2013, 110, 17462-17467. [CrossRef]

53. Chao de la Barca, J.M.; Bakhta, O.; Kalakech, H.; Simard, G.; Tamareille, S.; Catros, V.; Callebert, J.; Gadras, C.; Tessier, L.; Reynier, P.; et al. Metabolic signature of remote Ischemic Preconditioning Involving a Cocktail of Amino Acids and Biogenic Amines. J. Am. Heart Assoc. 2016, 5, e003891. [CrossRef] [PubMed]

54. Donato, M.; Goyeneche, M.A.; Garces, M.; Marchini, T.; Perez, V.; Del Mauro, J.; Hocht, C.; Rodriguez, M.; Evelson, P.; Gelpi, R.J. Myocardial triggers involved in activation of remote ischaemic preconditioning. Exp. Physiol. 2016, 101, 708-716. [CrossRef] [PubMed]

55. Shahid, M.; Tauseef, M.; Sharma, K.K.; Fahim, M. Brief femoral artery ischaemia provides protection against myocardial ischaemia-reperfusion injury in rats: The possible mechanisms. Exp. Physiol. 2008, 93, 954-968. [CrossRef] [PubMed]

56. Lambert, E.A.; Thomas, C.J.; Hemmes, R.; Eikelis, N.; Pathak, A.; Schlaich, M.P.; Lambert, G.W. Sympathetic nervous response to ischemia-reperfusion injury in humans is altered with remote ischemic preconditioning. Am. J. Physiol. Heart 2016, 311, H364-H370. [CrossRef] [PubMed]

57. Pickard, J.M.; Davidson, S.M.; Hausenloy, D.J.; Yellon, D.M. Co-dependence of the neural and humoral pathways in the mechanism of remote ischemic conditioning. Basic Res. Cardiol. 2016, 111, 50. [CrossRef]

58. Candilio, L.; Malik, A.; Hausenloy, D.J. Protection of organs other than the heart by remote ischemic conditioning. J. Cardiovasc. Med. 2013, 14, 193-205. [CrossRef] [PubMed]

59. Heusch, G.; Boengler, K.; Schulz, R. Cardioprotection: Nitric oxide, protein kinases, and mitochondria. Circulation 2008, 118, 1915-1919. [CrossRef]

60. Bartz, R.R.; Suliman, H.B.; Piantadosi, C.A. Redox mechanisms of cardiomyocyte mitochondrial protection. Front. Physiol. 2015, 6, 291. [CrossRef] [PubMed] 
61. Cao, Z.; Zhu, H.; Zhang, L.; Zhao, X.; Zweier, J.L.; Li, Y. Antioxidants and phase 2 enzymes in cardiomyocytes: Chemical inducibility and chemoprotection against oxidant and simulated ischemia-reperfusion injury. Exp. Biol. Med. 2006, 231, 1353-1364. [CrossRef] [PubMed]

62. Konstantinov, I.E.; Arab, S.; Li, J.; Coles, J.G.; Boscarino, C.; Mori, A.; Cukerman, E.; Dawood, F.; Cheung, M.M.; Shimizu, M.; et al. The remote ischemic preconditioning stimulus modifies gene expression in mouse myocardium. J. Thorac. Cardiovasc. Surg. 2005, 130, 1326-1332. [CrossRef] [PubMed]

63. Abdul-Ghani, S.; Heesom, K.J.; Angelini, G.D.; Suleiman, M.S. Cardiac phosphoproteomics during remote ischemic preconditioning: A role for the sarcomeric Z-disk proteins. BioMed Res. Int. 2014, 2014, 767812. [CrossRef]

64. Zitta, K.; Meybohm, P.; Gruenewald, M.; Cremer, J.; Zacharowski, K.D.; Scholz, J.; Steinfath, M.; Albrecht, M. Profiling of cell stress protein expression in cardiac tissue of cardiosurgical patients undergoing remote ischemic preconditioning: Implications for thioredoxin in cardioprotection. J. Transl. Med. 2015, 13, 34. [CrossRef] [PubMed]

65. Heusch, G. The coronary circulation as a target of cardioprotection. Circ. Res. 2016, 118, 1643-1658. [CrossRef]

66. Shimizu, M.; Konstantinov, I.E.; Kharbanda, R.K.; Cheung, M.H.; Redington, A.N. Effects of intermittent lower limb ischaemia on coronary blood flow and coronary resistance in pigs. Acta Physiol. 2007, 190, 103-109. [CrossRef]

67. Kono, Y.; Fukuda, S.; Hanatani, A.; Nakanishi, K.; Otsuka, K.; Taguchi, H.; Shimada, K. Remote ischemic conditioning improves coronary microcirculation in healthy subjects and patients with heart failure. Drug Des. Dev. Ther. 2014, 8, 1175-1181.

68. Grau, M.; Kollikowski, A.; Bloch, W. Remote ischemia preconditioning increases red blood cell deformability through red blood cell-nitric oxide synthase activation. Clin. Hemorheol. Microcirc. 2016, 63, 185-197. [CrossRef]

69. Shimizu, M.; Saxena, P.; Konstantinov, I.E.; Cherepanov, V.; Cheung, M.M.; Wearden, P.; Zhangdong, H.; Schmidt, M.; Downey, G.P.; Redington, A.N. Remote ischemic preconditioning decreases adhesion and selectively modifies functional responses of human neutrophils. J. Surg. Res. 2010, 158, 155-161. [CrossRef]

70. Pedersen, C.M.; Cruden, N.L.; Schmidt, M.R.; Lau, C.; Botker, H.E.; Kharbanda, R.K.; Newby, D.E. Remote ischemic preconditioning prevents systemic platelet activation associated with ischemia-reperfusion injury in humans. J. Thromb. Haemost. 2011, 9, 404-407. [CrossRef]

71. Stazi, A.; Scalone, G.; Laurito, M.; Milo, M.; Pelargonio, G.; Narducci, M.L.; Parrinello, R.; Figliozzi, S.; Bencardino, G.; Perna, F.; et al. Effect of remote ischemic preconditioning on platelet activation and reactivity induced by ablation for atrial fibrillation. Circulation 2014, 129, 11-17. [CrossRef] [PubMed]

72. Lanza, G.A.; Stazi, A.; Villano, A.; Torrini, F.; Milo, M.; Laurito, M.; Flego, D.; Aurigemma, C.; Liuzzo, G.; Crea, F. Effect of remote ischemic preconditioning on platelet activation induced by coronary procedures. Am. J. Cardiol. 2016, 117, 359-365. [CrossRef] [PubMed]

73. White, S.K.; Frohlich, G.M.; Sado, D.M.; Maestrini, V.; Fontana, M.; Treibel, T.A.; Tehrani, S.; Flett, A.S.; Meier, P.; Ariti, C.; et al. Remote ischemic conditioning reduces myocardial infarct size and edema in patients with ST-segment elevation myocardial infarction. JACC Cardiovasc. Interv. 2015, 8, 178-188. [CrossRef] [PubMed]

74. Crimi, G.; Pica, S.; Raineri, C.; Bramucci, E.; De Ferrari, G.M.; Klersy, C.; Ferlini, M.; Marinoni, B.; Repetto, A.; Romeo, M.; et al. Remote ischemic post-conditioning of the lower limb during primary percutaneous coronary intervention safely reduces enzymatic infarct size in anterior myocardial infarction: A randomized controlled trial. JACC Cardiovasc. Interv. 2013, 6, 1055-1063. [CrossRef] [PubMed]

75. Sloth, A.D.; Schmidt, M.R.; Munk, K.; Kharbanda, R.K.; Redington, A.N.; Schmidt, M.; Pedersen, L.; Sorensen, H.T.; Botker, H.E.; Investigators, C. Improved long-term clinical outcomes in patients with ST-elevation myocardial infarction undergoing remote ischaemic conditioning as an adjunct to primary percutaneous coronary intervention. Eur. Heart J. 2014, 35, 168-175. [CrossRef] [PubMed]

76. Gaspar, A.; Lourenco, A.P.; Pereira, M.A.; Azevedo, P.; Roncon-Albuquerque, R.; Marques, J.; Leite-Moreira, A.F. Randomized controlled trial of remote ischaemic conditioning in ST-elevation myocardial infarction as adjuvant to primary angioplasty (RIC-STEMI). Basic Res. Cardiol. 2018, 113, 14. [CrossRef] [PubMed]

77. Hausenloy, D.J.; Kharbanda, R.K.; Møller, U.K.; Ramlall, M.; Aarøe, J.; Butler, R. Effect of remote ischaemic conditioning on clinical outcomes in patients with acute myocardial infarction (CONDI-2/ERIC-PPCI): A single-blind randomised controlled trial. Lancet 2019. [CrossRef] 
78. Ibanez, B.; James, S.; Agewall, S.; Antunes, M.J.; Bucciarelli-Ducci, C.; Bueno, H.; Caforio, A.L.P.; Crea, F.; Goudevenos, J.A.; Halvorsen, S.; et al. Management of acute myocardial infarction in patients presenting with ST-segment elevation: The Task Force for the management of acute myocardial infarction in patients presenting with ST-segment elevation of the European Society of Cardiology. Eur. Heart J. 2018, 39, 119-177. [CrossRef] [PubMed]

79. Fihn, S.D.; Blankenship, J.C.; Alexander, K.P.; Bittl, J.A.; Byrne, J.G.; Fletcher, B.J.; Fonarow, G.C.; Lange, R.A.; Levine, G.N.; Maddox, T.M.; et al. ACC/AHA/AATS/PCNA/SCAI/STS focused update of the guideline for the diagnosis and management of patients with stable ischemic heart disease: A report of the American college of cardiology/American heart association task force on practice guidelines, and the American association for thoracic surgery, preventive cardiovascular nurses association, society for cardiovascular angiography and interventions, and society of thoracic surgeons. Circulation 2014, 130, 1749-1767. [PubMed]

80. Levine, G.N.; Bates, E.R.; Blankenship, J.C.; Bailey, S.R.; Bittl, J.A.; Cercek, B.; Chambers, C.E.; Ellis, S.G.; Guyton, R.A.; Hollenberg, S.M.; et al. ACC/AHA/SCAI focused update on primary percutaneous coronary intervention for patients with ST-elevation myocardial infarction: An update of the 2011 ACCF/AHA/SCAI guideline for percutaneous coronary intervention and the $2013 \mathrm{ACCF} / \mathrm{AHA}$ guideline for the management of ST-elevation myocardial infarction. J. Am. Coll. Cardiol. 2016, 67, 1235-1250.

81. Venugopal, V.; Hausenloy, D.J.; Ludman, A.; Di Salvo, C.; Kolvekar, S.; Yap, J.; Lawrence, D.; Bognolo, J.; Yellon, D.M. Remote ischaemic preconditioning reduces myocardial injury in patients undergoing cardiac surgery with cold-blood cardioplegia: A randomised controlled trial. Heart 2009, 95, 1567-1571. [CrossRef]

82. Hong, D.M.; Mint, J.J.; Kim, J.H.; Sohn, I.S.; Lim, T.W.; Lim, Y.J.; Bahk, J.H.; Jeon, Y. The effect of remote ischaemic preconditioning on myocardial injury in patients undergoing off-pump coronary artery bypass graft surgery. Anaesth. Intensive Care 2010, 38, 924-929. [CrossRef] [PubMed]

83. Young, P.J.; Dalley, P.; Garden, A.; Horrocks, C.; La Flamme, A.; Mahon, B.; Miller, J.; Pilcher, J.; Weatherall, M.; Williams, J.; et al. A pilot study investigating the effects of remote ischemic preconditioning in high-risk cardiac surgery using a randomised controlled double-blind protocol. Basic Res. Cardiol. 2012, 107, 256. [CrossRef]

84. Kottenberg, E.; Musiolik, J.; Thielmann, M.; Jakob, H.; Peters, J.; Heusch, G. Interference of propofol with signal transducer and activator of transcription 5 activation and cardioprotection by remote ischemic preconditioning during coronary artery bypass grafting. J. Thorac. Cardiovasc. Surg. 2014, 147, 376-382. [CrossRef] [PubMed]

85. Candilio, L.; Malik, A.; Ariti, C.; Barnard, M.; Di Salvo, C.; Lawrence, D.; Hayward, M.; Yap, J.; Roberts, N.; Sheikh, A.; et al. Effect of remote ischaemic preconditioning on clinical outcomes in patients undergoing cardiac bypass surgery: A randomised controlled clinical trial. Heart 2015, 101, 185-192. [CrossRef]

86. Walsh, M.; Whitlock, R.; Garg, A.X.; Legare, J.F.; Duncan, A.E.; Zimmerman, R.; Miller, S.; Fremes, S.; Kieser, T.; Karthikeyan, G.; et al. Effects of remote ischemic preconditioning in high-risk patients undergoing cardiac surgery (remote IMPACT): A randomized controlled trial. Can. Med. Assoc. J. 2016, 188, 329-336. [CrossRef]

87. Pinaud, F.; Corbeau, J.J.; Baufreton, C.; Binuani, J.P.; De Brux, J.L.; Fouquet, O.; Angoulvant, D.; Furber, A.; Prunier, F. Remote ischemic preconditioning in aortic valve surgery: Results of a randomized controlled study. J. Cardiol. 2016, 67, 36-41. [CrossRef]

88. Song, Y.; Song, J.W.; Lee, S.; Jun, J.H.; Kwak, Y.L.; Shim, J.K. Effects of remote ischemic preconditioning in patients with concentric myocardial hypertrophy: A randomized, controlled trial with molecular insights. Int. J. Cardiol. 2017, 249, 36-41. [CrossRef]

89. Javaherforoosh Zadeh, F.; Moadeli, M.; Soltanzadeh, M.; Janatmakan, F. Effect of remote ischemic preconditioning on troponin I in CABG. Anesth. Pain Med. 2017, 7, e12549. [CrossRef]

90. Wang, H.; Lyu, Y.; Liao, Q.; Jin, L.; Xu, L.; Hu, Y.; Yu, Y.; Guo, K. Effects of remote ischemic preconditioning in patients undergoing off-pump coronary artery bypass graft surgery. Front. Physiol. 2019, 10, 495. [CrossRef] [PubMed]

91. Jin, X.; Wang, L.; Li, L.; Zhao, X. Protective effect of remote ischemic pre-conditioning on patients undergoing cardiac bypass valve replacement surgery: A randomized controlled trial. Exp. Ther. Med. 2019, 17, 2099-2106. [CrossRef] [PubMed] 
92. Meybohm, P.; Bein, B.; Brosteanu, O.; Cremer, J.; Gruenewald, M.; Stoppe, C.; Coburn, M.; Schaelte, G.; Boning, A.; Niemann, B.; et al. A multicenter trial of remote ischemic preconditioning for heart surgery. N. Engl. J. Med. 2015, 373, 1397-1407. [CrossRef] [PubMed]

93. Hausenloy, D.J.; Candilio, L.; Evans, R.; Ariti, C.; Jenkins, D.P.; Kolvekar, S.; Knight, R.; Kunst, G.; Laing, C.; Nicholas, J.; et al. Remote ischemic preconditioning and outcomes of cardiac surgery. N. Engl. J. Med. 2015, 373, 1408-1417. [CrossRef] [PubMed]

94. Coverdale, N.S.; Hamilton, A.; Petsikas, D.; McClure, R.S.; Malik, P.; Milne, B.; Saha, T.; Zelt, D.; Brown, P.; Payne, D.M. Remote ischemic preconditioning in high-risk cardiovascular surgery patients: A randomized-controlled trial. Semin. Thorac. Cardiovasc. Surg. 2018, 30, 26-33. [CrossRef] [PubMed]

95. Hong, D.M.; Lee, E.H.; Kim, H.J.; Min, J.J.; Chin, J.H.; Choi, D.K.; Bahk, J.H.; Sim, J.Y.; Choi, I.C.; Jeon, Y. Does remote ischaemic preconditioning with postconditioning improve clinical outcomes of patients undergoing cardiac surgery? Remote ischaemic preconditioning with postconditioning outcome trial. Eur. Heart J. 2014, 35, 176-183. [CrossRef] [PubMed]

96. Cho, Y.J.; Lee, E.H.; Lee, K.; Kim, T.K.; Hong, D.M.; Chin, J.H.; Choi, D.K.; Bahk, J.H.; Sim, J.Y.; Choi, I.C.; et al. Long-term clinical outcomes of remote ischemic preconditioning and postconditioning outcome (RISPO) trial in patients undergoing cardiac surgery. Int. J. Cardiol. 2017, 231, 84-89. [CrossRef]

97. Xie, J.; Zhang, X.; Xu, J.; Zhang, Z.; Klingensmith, N.J.; Liu, S.; Pan, C.; Yang, Y.; Qiu, H. Effect of remote ischemic preconditioning on outcomes in adult cardiac surgery: A systematic review and meta-analysis of randomized controlled studies. Anesth. Analg. 2018, 127, 30-38. [CrossRef]

98. Jiang, Q.; Xiang, B.; Wang, H.; Huang, K.; Kong, H.; Hu, S. Remote ischaemic preconditioning ameliorates sinus rhythm restoration rate through Cox maze radiofrequency procedure associated with inflammation reaction reduction. Basic Res. Cardiol. 2019, 114, 14. [CrossRef]

99. Benstoem, C.; Stoppe, C.; Liakopoulos, O.J.; Ney, J.; Hasenclever, D.; Meybohm, P.; Goetzenich, A. Remote ischaemic preconditioning for coronary artery bypass grafting (with or without valve surgery). Cochrane Database Syst. Rev. 2017, 5, Cd011719. [CrossRef]

100. Thielmann, M.; Sharma, V.; Al-Attar, N.; Bulluck, H.; Bisleri, G.; Bunge, J.J.H.; Czerny, M.; Ferdinandy, P.; Frey, U.H.; Heusch, G.; et al. ESC joint working groups on cardiovascular surgery and the cellular biology of the heart position paper: Perioperative myocardial injury and infarction in patients undergoing coronary artery bypass graft surgery. Eur. Heart J. 2017, 38, 2392-2407. [CrossRef]

101. Nishimura, R.A.; Otto, C.M.; Bonow, R.O.; Carabello, B.A.; Erwin, J.P.; Fleisher, L.A.; Jneid, H.; Mack, M.J.; McLeod, C.J.; O'Gara, P.T.; et al. AHA/ACC focused update of the 2014 AHA/ACC guideline for the management of patients with valvular heart disease: A report of the American college of cardiology/American heart association task force on clinical practice guidelines. Circulation 2017, 135, e1159-e1195. [CrossRef] [PubMed]

102. Bosnjak, Z.J.; Ge, Z.D. The application of remote ischemic conditioning in cardiac surgery. F1000 Res. 2017, 6, 928. [CrossRef] [PubMed]

103. Kottenberg, E.; Thielmann, M.; Bergmann, L.; Heine, T.; Jakob, H.; Heusch, G.; Peters, J. Protection by remote ischemic preconditioning during coronary artery bypass graft surgery with isoflurane but not propofol-A clinical trial. Acta Anaesthesiol. Scand. 2012, 56, 30-38. [CrossRef] [PubMed]

104. Kleinbongard, P.; Peters, J.; Jakob, H.; Heusch, G.; Thielmann, M. Persistent survival benefit from remote ischemic pre-conditioning in patients undergoing coronary artery bypass surgery. J. Am. Coll. Cardiol. 2018, 71, 252-254. [CrossRef] [PubMed]

105. Landoni, G.; Greco, T.; Biondi-Zoccai, G.; Nigro Neto, C.; Febres, D.; Pintaudi, M.; Pasin, L.; Cabrini, L.; Finco, G.; Zangrillo, A. Anaesthetic drugs and survival: A Bayesian network meta-analysis of randomized trials in cardiac surgery. Br. J. Anaesth. 2013, 111, 886-896. [CrossRef] [PubMed]

106. Zangrillo, A.; Musu, M.; Greco, T.; Di Prima, A.L.; Matteazzi, A.; Testa, V.; Nardelli, P.; Febres, D.; Monaco, F.; Calabro, M.G.; et al. Additive effect on survival of anaesthetic cardiac protection and remote ischemic preconditioning in cardiac surgery: A bayesian network meta-analysis of randomized trials. PLoS ONE 2015, 10, e0134264. [CrossRef] [PubMed]

107. Benstoem, C.; Goetzenich, A.; Stoppe, C. The role of propofol for remote ischaemic preconditioning in the setting of cardiac surgery-A Cochrane systematic review. Br. J. Anaesth. 2017, 119, 1234-1235. [CrossRef] [PubMed] 
108. Benstoem, C.; Goetzenich, A.; Autschbach, R.; Marx, G.; Stoppe, C.; Breuer, T. Volatile anesthetics versus propofol in the cardiac surgical setting of remote ischemic preconditioning: A secondary analysis of a Cochrane Systematic Review. Minerva Anestesiol. 2018, 84, 1298-1306. [CrossRef] [PubMed]

109. Behmenburg, F.; van Caster, P.; Bunte, S.; Brandenburger, T.; Heinen, A.; Hollmann, M.W.; Huhn, R. Impact of anesthetic regimen on remote ischemic preconditioning in the rat heart in vivo. Anesth. Analg. 2018, 126, 1377-1380. [CrossRef]

110. Cho, Y.J.; Nam, K.; Kim, T.K.; Choi, S.W.; Kim, S.J.; Hausenloy, D.J.; Jeon, Y. Sevoflurane, propofol and carvedilol block myocardial protection by limb remote ischemic preconditioning. Int. J. Mol. Sci. 2019, 20, 269. [CrossRef]

111. Suematsu, Y.; Anttila, V.; Takamoto, S.; del Nido, P. Cardioprotection afforded by ischemic preconditioning interferes with chronic beta-blocker treatment. Scand. Cardiovasc. J. 2004, 38, 293-299. [CrossRef] [PubMed]

112. Lange, M.; Smul, T.M.; Blomeyer, C.A.; Redel, A.; Klotz, K.N.; Roewer, N.; Kehl, F. Role of the beta1-adrenergic pathway in anesthetic and ischemic preconditioning against myocardial infarction in the rabbit heart in vivo. Anesthesiology 2006, 105, 503-510. [CrossRef] [PubMed]

113. Spear, J.F.; Prabu, S.K.; Galati, D.; Raza, H.; Anandatheerthavarada, H.K.; Avadhani, N.G. Beta1-adrenoreceptor activation contributes to ischemia-reperfusion damage as well as playing a role in ischemic preconditioning. Am. J. Physiol. Heart Circ. Physiol. 2007, 292, H2459-H2466. [CrossRef] [PubMed]

114. Zhou, C.; Liu, Y.; Yao, Y.; Zhou, S.; Fang, N.; Wang, W.; Li, L. Beta-blockers and volatile anesthetics may attenuate cardioprotection by remote preconditioning in adult cardiac surgery: A meta-analysis of 15 randomized trials. J. Cardiothorac. Vasc. Anesth. 2013, 27, 305-311. [CrossRef] [PubMed]

115. Kleinbongard, P.; Neuhauser, M.; Thielmann, M.; Kottenberg, E.; Peters, J.; Jakob, H.; Heusch, G. Confounders of cardioprotection by remote ischemic preconditioning in patients undergoing coronary artery bypass grafting. Cardiology 2016, 133, 128-133. [CrossRef] [PubMed]

116. Schulman, D.; Latchman, D.S.; Yellon, D.M. Effect of aging on the ability of preconditioning to protect rat hearts from ischemia-reperfusion injury. Am. J. Physiol. Heart Circ. Physiol. 2001, 281, H1630-H1636. [CrossRef] [PubMed]

117. Abete, P.; Ferrara, N.; Cacciatore, F.; Madrid, A.; Bianco, S.; Calabrese, C.; Napoli, C.; Scognamiglio, P.; Bollella, O.; Cioppa, A.; et al. Angina-induced protection against myocardial infarction in adult and elderly patients: A loss of preconditioning mechanism in the aging heart? J. Am. Coll. Cardiol. 1997, 30, 947-954. [CrossRef]

118. Przyklenk, K. Efficacy of cardioprotective 'conditioning' strategies in aging and diabetic cohorts: The co-morbidity conundrum. Drugs Aging 2011, 28, 331-343. [CrossRef]

119. Sloth, A.D.; Schmidt, M.R.; Munk, K.; Schmidt, M.; Pedersen, L.; Sorensen, H.T.; Botker, H.E.; Investigators, C. Impact of cardiovascular risk factors and medication use on the efficacy of remote ischaemic conditioning: Post hoc subgroup analysis of a randomised controlled trial. BMJ Open 2015, 5, e006923. [CrossRef]

120. Wu, Q.; Wang, T.; Chen, S.; Zhou, Q.; Li, H.; Hu, N.; Feng, Y.; Dong, N.; Yao, S.; Xia, Z. Cardiac protective effects of remote ischaemic preconditioning in children undergoing tetralogy of fallot repair surgery: A randomized controlled trial. Eur. Heart J. 2018, 39, 1028-1037. [CrossRef]

121. Miki, T.; Itoh, T.; Sunaga, D.; Miura, T. Effects of diabetes on myocardial infarct size and cardioprotection by preconditioning and postconditioning. Cardiovasc. Diabetol. 2012, 11, 67. [CrossRef] [PubMed]

122. Wider, J.; Undyala, V.V.R.; Whittaker, P.; Woods, J.; Chen, X.; Przyklenk, K. Remote ischemic preconditioning fails to reduce infarct size in the Zucker fatty rat model of type-2 diabetes: Role of defective humoral communication. Basic Res. Cardiol. 2018, 113, 16. [CrossRef]

123. Ferdinandy, P.; Hausenloy, D.J.; Heusch, G.; Baxter, G.F.; Schulz, R. Interaction of risk factors, comorbidities, and comedications with ischemia/reperfusion injury and cardioprotection by preconditioning, postconditioning, and remote conditioning. Pharmacol. Rev. 2014, 66, 1142-1174. [CrossRef] [PubMed]

124. Ye, Y.; Perez-Polo, J.R.; Aguilar, D.; Birnbaum, Y. The potential effects of anti-diabetic medications on myocardial ischemia-reperfusion injury. Basic Res. Cardiol. 2011, 106, 925-952. [CrossRef]

125. Kottenberg, E.; Thielmann, M.; Kleinbongard, P.; Frey, U.H.; Heine, T.; Jakob, H.; Heusch, G.; Peters, J. Myocardial protection by remote ischaemic pre-conditioning is abolished in sulphonylurea-treated diabetics undergoing coronary revascularisation. Acta Anaesthesiol. Scand. 2014, 58, 453-462. [CrossRef] [PubMed] 
126. Epps, J.A.; Smart, N.A. Remote ischaemic conditioning in the context of type 2 diabetes and neuropathy: The case for repeat application as a novel therapy for lower extremity ulceration. Cardiovasc. Diabetol. 2016, 15, 130. [CrossRef]

127. Hausenloy, D.J.; Garcia-Dorado, D.; Botker, H.E.; Davidson, S.M.; Downey, J.; Engel, F.B.; Jennings, R.; Lecour, S.; Leor, J.; Madonna, R.; et al. Novel targets and future strategies for acute cardioprotection: Position paper of the european society of cardiology working group on cellular biology of the heart. Cardiovasc. Res. 2017, 113, 564-585. [CrossRef]

128. Hausenloy, D.J.; Yellon, D.M. Combination therapy to target reperfusion injury after ST-segment-elevation myocardial infarction: A more effective approach to cardioprotection. Circulation 2017, 136, 904-906. [CrossRef]

129. Hausenloy, D.J.; Heusch, G. Translating cardioprotection for patient benefit: The EU-CARDIOPROTECTION COST Action. J. Am. Coll. Cardiol. 2019, 73, 2001-2003. [CrossRef]

(C) 2019 by the authors. Licensee MDPI, Basel, Switzerland. This article is an open access article distributed under the terms and conditions of the Creative Commons Attribution (CC BY) license (http://creativecommons.org/licenses/by/4.0/). 